Kinga Hinc

Uniwersytet Gdański

\title{
Zmiany w egzaminie gimnazjalnym - perspektywa nauczycieli uczniów z niepełnosprawnością intelektualną w stopniu lekkim
}

W artykule przedstawiono analizę danych empirycznych dotyczących wprowadzonych zmian w egzaminach gimnazjalnych z punktu widzenia nauczycieli uczniów z niepełnosprawnością intelektualną w stopniu lekkim. Podstawą analizy jest krótki historyczny zarys zmian w egzaminach gimnazjalnych oraz przemiany w zakresie dostosowania tego egzaminu do potrzeb uczniów z niepełnosprawnością intelektualną w stopniu lekkim. Po przedstawieniu opisu koncepcji metodologicznej autor analizuje wyniki badań, wskazując nauczycielskie oceny przemian w systemie egzaminacyjnym. Niemałą część zajmuje również ujęcie perspektywy nauczycieli na temat planowanej reformy likwidacji gimnazjum.

Słowa kluczowe: egzamin gimnazjalny, nauczyciel, niepełnosprawność intelektualna w stopniu lekkim, reforma edukacyjna

\section{Changes in the middle school exam in the perspective of staff teaching students with mild intellectual disabilities}

The article presents analysis of empirical data focusing on changes introduced in the middle school exams in the perspective of staff teaching students with mild intellectual disabilities. The background of the analysis is a brief historical outline of modifications and rearrangements of the middle school exams that have been introduced over the time. Having provided a description of the methodological concept, the author analyses research findings, pointing out teachers' opinion on the issue of middle school reforms: either past changes of the examination system or current educational reform which has already introduced the process of replacing middle schools from educational system in Poland.

Keywords: middle school exam, teacher, mild intellectual disability, educational reform

\section{Wprowadzenie}

Na przestrzeni ostatnich kilku dekad doszło do znaczących przemian i reform $\mathrm{w}$ polskim systemie edukacyjnym. Istotną rolę $\mathrm{w}$ toku zachodzących zmian odgrywają nauczyciele - to oni w głównej mierze decydują o powodzeniu bądź też 
klęsce wprowadzanych zmian. Magdalena Ślusarczyk [2010, s. 98], przytaczając pogląd Torstena Husena, tłumaczy to zjawisko w ten sposób, iż to na nauczycielach spoczywa odpowiedzialność za praktyczne wdrażanie zaplanowanych przemian. Efektywność reform uzależniona jest od tego, na ile nauczyciele utożsamiają się z projektowanymi zmianami.

Kwestia reform, zapoczątkowanych między innymi przywróceniem nieistniejącego od 1948 r. gimnazjum [por. Draus, Terlecki 2005], wielokrotnie była poddawana ocenom, w tym ocenom nauczycieli. Kazimierz Denek - pedagog, profesor nauk humanistycznych i nauczyciel akademicki, po kilku latach od wprowadzenia reformy wskazywał, że system edukacji w Polsce nie jest doskonały i reforma jest koniecznością niepodlegającą dyskusji. Dostrzegał pozytywy przemian między innymi w takich aspektach jak: objęcie szkół przez samorządy, system egzaminowania zewnętrznego ograniczający subiektywne ocenianie uczniów oraz samodzielność szkól, która wzbogaca ofertę edukacyjną [Denek 2005, s. 32-37]. Konieczność przemian w systemie edukacji podnoszona była też przez autora w kolejnych latach [Denek 2008, s. 21-23]. Głos w tej kwestii zabierali także inni przedstawiciele środowiska naukowego pedagogów [por. Szymański 2004, s. 111]. Warto zauważyć, że za nadrzędne cele reformy oświaty, z tytułu której wprowadzono gimnazjum, uznano: wzrost poziomu edukacji wśród uczniów poprzez rozpowszechnienie szkolnictwa na szczeblu średnim i wyższym, wyrównanie szans $w$ dostępie do edukacji na wszystkich jej poziomach, a także poprawę jakości edukacji dzięki zmianom programów nauczania. Maria Czerepaniak-Walczak, pisząc o funkcji powstania gimnazjum zwraca uwagę na słowa wypowiedziane w styczniu 1999 roku przez Ministra Edukacji Narodowej, z których wynika, że założenie gimnazjum nie jest celem samym w sobie, a jedynie drogą do osiągnięcia celu, jakim jest upowszechnienie wykształcenia średniego [Czerepaniak-Walczak 2002, s. 39]. Szczególnym wyrazem ocen reformy oświaty są głosy środowisk nauczycielskich. W roku szkolnym 1998/99 przeprowadzono wśród pedagogów dwa sondaże na temat przemian w edukacji. $Z$ pierwszego z nich - dokonanego przez MEN wynika, iż znaczna większość badanych (niespełna $60 \%$ ) opowiedziała się za koniecznością wprowadzenia przekształceń. Zupełnie odmienny obraz wyłaniał się z sondażu lektury pisma prowadzonego przez organ ZNP "Głos Nauczycielski” - najbardziej prestiżowego pisma z perspektywy nauczycieli. W tym sondażu stosunek nauczycieli do zmian nie był już tak przychylny [Zahorska 1999, s. 116]. Badania przeprowadzane w kolejnych latach przez Marię Kocór [2006, 2014] pozwalają zauważyć, iż z biegiem czasu liczba zwolenników wprowadzonej do polskich szkół 1 września 1999 roku reformy malała.

$\mathrm{W}$ odniesieniu do kształcenia specjalnego temat reform nie doczekał się tak obszernej liczby badań, chociaż analiz nie brakuje, $\mathrm{w}$ tym także w polu zewnętrz- 
nych egzaminów dla uczniów z niepełnosprawnością [por. Sadowska 2013; Sadowska, Janiszewska-Nieścioruk 2015]. W ich przestrzeni brakuje jednak takich badań, w których oceny przemian rozpoznawane są z perspektywy nauczycieli kształcenia specjalnego. Sytuacja ta skłoniła autorkę tekstu do podjęcia badań $\mathrm{w}$ tym obszarze. Ponieważ temat reformy jest tak obszerną dziedziną, iż nie sposób podjać się wnikliwych rozważań w odniesieniu do każdego szczebla edukacji, obszar zainteresowań został zawężony do zmian na etapie gimnazjalnym, a precyzyjnie mówiąc do zmian w egzaminie zewnętrznym na tym etapie. Czas realizacji badań przypadał na ostatni rok szkolny przed reformą wprowadzoną przez rząd Beaty Szydło, której jednym z elementów była likwidacja gimnazjów. Badania te stworzyły pierwszą, a zarazem jedyną możliwość poznania perspektywy nauczycieli uczniów z niepełnosprawnością intelektualną $\mathrm{w}$ stopniu lekkim $\mathrm{w}$ trzech polach: $\mathrm{w}$ odsłonie retrospekcyjnego podejścia do tematu, stanowisk na obecną sytuację oraz stanowisk odnoszących się do jeszcze nieurzeczywistnionych zmian, które miały nastąpić w kolejnym roku szkolnym.

Krótki zarys historyczny na temat przemian $\mathrm{w}$ przeprowadzanym egzaminie gimnazjalnym oraz dostosowania tego egzaminu do potrzeb uczniów z niepełnosprawnością intelektualną w stopniu lekkim, stanowiący kolejny element opracowania, stanowi tło dla prowadzonych analiz wypowiedzi nauczycieli. Poprzedzone one także będą informacją o projekcie badawczym i osobach nim objętych.

\section{Krótka lekcja historii - egzamin gimnazjalny w świetle przepisów prawa oświatowego (1999-2017)}

Przekształcenie dotychczas istniejącego dwustopniowego systemu szkolnictwa w model trójstopniowy nastąpiło na mocy Ustawy z dnia 8 stycznia 1999 r. przepisu wprowadzającego reformę ustroju szkolnego [Dz. U. $1999 \mathrm{Nr} 12$, poz. 96]. Trzy lata później, tj. w roku szkolnym 2001/2002 odbył się pierwszy egzamin gimnazjalny.

Pierwszą wykładnią dla przeprowadzenia tego egzaminu było Rozporządzenie Ministra Edukacji Narodowej z dnia 19 kwietnia 1999 r. w sprawie zasad oceniania, klasyfikowania i promowania uczniów i słuchaczy oraz przeprowadzania egzaminów i sprawdzianów w szkołach publicznych [Dz. U. Nr 41, poz. 413 oraz z 2000 r. Nr 6, poz. 72 i Nr 115, poz. 1201]. Kolejna regulacja nastąpiła na mocy Rozporządzenia Ministra Edukacji Narodowej z dnia 21 marca 2001 roku w sprawie warunków i sposobu oceniania, klasyfikowania i promowania uczniów i słuchaczy oraz przeprowadzania egzaminów i sprawdzianów w szkołach publicznych [Dz. U. z 2001 r. Nr 29, poz. 323]. W § 28.1. zapisano, że uczniowie z potwierdzonymi dysfunkcjami mają prawo przystąpić do egzaminu gimnazjalnego $\mathrm{w}$ formie 
dostosowanej do ich dysfunkcji. Formułę egzaminu stanowiły dwie części: humanistyczna oraz matematyczno-przyrodnicza. Arkusze egzaminacyjne przygotowane zostały przez Centralną Komisję Egzaminacyjną. Dla każdej z części przygotowano arkusze zgodnie ze standardami wymagań egzaminacyjnych. Za standard wymagań egzaminacyjnych określano wzór wymagań, na które napotykał uczeń przystępujący do egzaminu [Konarzewski 2004, s. 127].

Od 2009 roku przeprowadzano egzamin gimnazjalny zgodnie z Rozporządzeniem Ministra Edukacji Narodowej z dnia 30 kwietnia 2007r. w sprawie warunków i sposobu oceniania, klasyfikowania i promowania uczniów i słuchaczy oraz przeprowadzania sprawdzianów i egzaminów w szkołach publicznych [Dz. U. z 2007 r. Nr 73, poz. 562]. Egzamin składał się z trzech części - oprócz wiadomości i umiejętności w zakresie przedmiotów humanistycznych i matematyczno-przyrodniczych weryfikowano kompetencje w obszarze nowożytnego języka obcego. Uczniowie przystępowali do egzaminu z jednego z sześciu możliwych języków obcych - mieli do wyboru język angielski, francuski, hiszpański, włoski, niemiecki, rosyjski [CKE 2004].

W roku szkolnym 2011/2012 przeprowadzono pierwszy raz egzamin gimnazjalny, który weryfikował stopień opanowania przez uczniów wiadomości i umiejętności zawartych w wymaganiach ogólnych i szczegółowych podstawy programowej kształcenia ogólnego, a nie jak miało to miejsce do tej pory - w standardach wymagań egzaminacyjnych opracowanych przez Centralną Komisję Egzaminacyjną. Wykładnią wymagań dla egzaminu było Rozporządzenie Ministra Edukacji Narodowej z dnia 23 grudnia 2008r. w sprawie podstawy programowej wychowania przedszkolnego oraz kształcenia ogólnego w poszczególnych typach szkół [Dz. U. z 2009 r. Nr 4, poz. 17]. Egzamin składał się z trzech części, jednak każda $\mathrm{z}$ nich posiadała inną strukturę. W przypadku egzaminu z części humanistycznej uczniowie rozwiązywali zadania z zakresu języka polskiego, które mogły mieć formę zarówno zamkniętą jak i otwartą, a także z historii i wiedzy o społeczeństwie - z tych przedmiotów wszystkie zadania były o charakterze zamkniętym. W części matematyczno-przyrodniczej znajdowały się zadania z matematyki, które, podobnie do zadań z języka polskiego, występowały w dwóch formach zamkniętej i otwartej oraz zadania z przedmiotów przyrodniczych: biologii, chemii, geografii oraz fizyki - te zadania miały wyłącznie formę zamkniętą [Informator o egzaminie gimnazjalnym od roku szkolnego 2011/2012]. Taka formuła egzaminu obowiązywała w istocie do $2017 \mathrm{r}$.

Ten krótki przegląd wskazuje, że od czasu przeprowadzenia pierwszego egzaminu gimnazjalnego kilkukrotnie podlegał on modyfikacjom - zarówno pod względem kryteriów jak i jego struktury. Istotne jest, że sygnalizowane zmiany w ciągu tych 16 lat obejmowały swoim zasięgiem wszystkich uczniów, a więc i uczniów ze specjalnymi potrzebami edukacyjnymi, w tym z niepełnospraw- 
nością intelektualną w stopniu lekkim. Słowa zawarte w zeszycie „Biblioteczki Reformy" wskazują, że cele wdrażanych reform uwzględniać miały potrzeby różnych uczniów. „Jednym z założeń reformy oświaty było stworzenie takiej sytuacji, w której wszystkie dzieci miałyby równe szanse, a nauczanie zostałoby dostosowane do specyficznych potrzeb uczniów, których możliwości są ograniczane przez różnego rodzaju czynniki biologiczne" [Chrostowska, Mosiek 2001, s. 51]. Do zadań, jakie miała spełniać reforma należały: wspieranie rozwoju oraz realizowanie programów dostosowanych do możliwości uczniów.

Istotnym elementem zmian była kwestia dostosowania egzaminów gimnazjalnych dla uczniów o specjalnych potrzebach edukacyjnych. Biorąc pod uwagę wymienione okoliczności powołano Zespół ds. Uczniów o Specjalnych Potrzebach Edukacyjnych. Został on podzielony na cztery podzespoły, wśród których grupa pod przewodnictwem Ewy Mąkosy zajmowała się sprawami dotyczącymi uczniów z niepełnosprawnością intelektualną w stopniu lekkim i mózgowym porażeniem dziecięcym [Barłóg 2008, s. 36-38]. Specjaliści formułujący zalecenia do pierwszego egzaminu gimnazjalnego dla uczniów z niepełnoprawnością intelektualną w stopniu lekkim zdecydowali się na przeprowadzenie go zgodnie z obowiązującymi standardami wymagań egzaminacyjnych. Stworzono natomiast wytyczne dotyczące dostosowania zadań dla tej grupy uczniów: polecenia i instrukcje miały być proste, krótkie i zrozumiałe dla ucznia, a w razie potrzeby dopuszczalna była również pomoc nauczyciela w odczytaniu poleceń; ważne było, aby tekst był czytelny pod względem graficznym; czas przeznaczony na napisanie egzaminu można było wydłużyć do $50 \%$; specjaliści zwrócili uwagę na trudności, jakie towarzyszą uczniom w myśleniu abstrakcyjnym, które jest zastępowane myśleniem konkretno-obrazowym - przy konstruowaniu arkuszy egzaminacyjnych należało zwracać szczególną uwagę na tę cechę; zaznaczono, aby $\mathrm{w}$ tekstach pojawiły się zadania $\mathrm{w}$ różnorodnych formach; arkusze miały zawierać właściwy dobór tekstów literackich; uczniowie mieli tworzyć krótkie wypowiedzi pisemne [Chrostowska, Mosiek 2001, s. 58-59]. W kolejnych latach dostosowania egzaminu do potrzeb uczniów dookreślane były w komunikatach CKE. Zauważyć należy, że przepisy oświatowe nie dookreślają zróżnicowania wymagań egzaminacyjnych dla uczniów, którzy zobowiązani są przystąpić do egzaminu. Kwestia ta jest wyraźnie dyskusyjna w odniesieniu do uczniów z upośledzeniem umysłowym w stopniu lekkim. Decyzja odnośnie zakresu wymagań dla uczniów z niepełnosprawnością intelektualną $\mathrm{w}$ istocie oddana jest $\mathrm{w}$ ręce osób zaangażowanych w przygotowywanie zadań egzaminacyjnych, co odczytywać można jako marginalizowanie pewnych podmiotów edukacji, przy zachowaniu oficjalnych pozorów równości [por. Sadowska 2013]. Dostosowanie egzaminu obejmuje dla przykładu: zaznaczenie odpowiedzi w zestawie egzaminacyjnym (w zadaniach zamkniętych) - bez przenoszenia ich na kartę odpowiedzi; wydłużenie czasu egzaminu: z części humanistycznej i matematyczno-przyrod- 
niczej - maksymalnie o 60 minut każdą z części; z języka obcego nowożytnego maksymalnie o 45 minut; a także możliwości przystąpienia do egzaminu w oddzielnej sali (tylko wówczas gdy uczeń korzysta z wydłużenia czasu) [por. Komunikat dyrektora CKE z dnia 31 marca 2010 r.]. Komunikat wydany we wrześniu 2016 roku przez dyrektora Centralnej Komisji Egzaminacyjnej informował o szczegółowych sposobach dostosowania warunków i form przeprowadzania egzaminu gimnazjalnego w roku szkolnym 2016/2017. Dostosowanie to polegało na przygotowaniu odrębnych arkuszy adekwatnych do możliwości i potrzeb uczniów, w tym osób z niepełnosprawnością intelektualną w stopniu lekkim, które obejmowały: przedłużenie czasu (z historii i wiedzy o społeczeństwie, przedmiotów przyrodniczych i języka obcego nowożytnego na poziomie podstawowym o 20 minut, z języka obcego nowożytnego na poziomie rozszerzonym o 30 minut oraz z języka polskiego i matematyki o 45 minut); dostosowanie do potrzeb uczniów zadań ze słuchu obowiązujących na egzaminie z języków obcych nowożytnych; w zadaniach zamkniętych zaznaczenie odpowiedzi w arkuszu zadań, a także zapewnienie obecności specjalisty jeśli to konieczne do uzyskania prawidłowego kontaktu z uczniem oraz pomocy w obsłudze specjalistycznego sprzętu i środków dydaktycznych [por. Komunikat dyrektora CKE z dnia 9 września 2016].

Ocena reformatorskiego zamysłu zewnętrznego sprawdzania efektów kształcenia, realizowanego pod hasłem podnoszenia jakości w szkolnictwie budzi ciekawość poznawczą. $\mathrm{W}$ imię tej jakości należy z pewnością odsłaniać chybione projekty zewnętrznego oceniania. Sławomira Sadowska [2013], stawiając w polu analiz arkusze egzaminu gimnazjalnego dla uczniów z niepełnosprawnością intelektualną, wyniki egzaminu, komunikaty CKE i przepisy oświatowe regulujące przeprowadzenie egzaminu gimnazjalnego w 2012 r., sformułowała krytyczne wnioski. Zwracała uwagę, że działaniom reformatorów zdaje się towarzyszyć ukryte przeświadczenie, że sprawdzanie i ocenianie umiejętności mniejszości (a taką grupą są uczniowie ze specjalnymi potrzebami edukacyjnymi) może być owiane tajemnicą zarówno w warstwie wymagań edukacyjnej, jak i jawności wyników. Podkreślała, że nie można nie dostrzegać wagi szerokiego wachlarza dostosowania warunków przeprowadzania sprawdzianu lub egzaminu gimnazjalnego do potrzeb uczniów, jakie przedstawia komunikat CKE. Nie znaczy to jednak, że osłabić to może uwagi dotyczące kwestii kluczowych - wymagań egzaminacyjnych. Analizy konkluduje słowami: „Zaspokojenie potrzeb specjalnych z poziomu ucznia musi odwoływać się do innych źródeł niż te, jakimi próbuje nas uwieść MEN czy CKE. Nie można wpaść w pułapkę doceniania tego, co zostało dookreślone $\mathrm{w}$ zakresie dostosowania warunków przeprowadzania zewnętrznych egzaminów do potrzeb uczniów, by można było powiedzieć, że umiemy z mądrością reprezentować pole potrzeb edukacji specjalnej" [Sadowska 2013, s. 332]. Jak te kwestie widzą nauczyciele? 


\section{Założenia badawcze oraz charakterystyka grupy badawczej}

Celem przeprowadzonych badań było dokonanie opisu nauczycielskiej perspektywy zmian w egzaminie gimnazjalnym dla uczniów z niepełnosprawnością intelektualną w stopniu lekkim. Realizację tego celu zaplanowano z zastosowaniem techniki wywiadu nieskategoryzowanego, nazywanego również niestandaryzowanym lub swobodnym, który przeprowadzono z nauczycielami pracującymi z uczniami z niepełnosprawnością intelektualną w stopniu lekkim na etapie szkoły gimnazjalnej. Wywiad był zogniskowany wobec tematu zmian w egzaminie gimnazjalnym. Zagadnienia poruszane podczas wywiadu dotyczyły zarówno tych zmian, które miały miejsce, jak również reform, które mają dopiero nastąpić. Nauczyciele na podstawie własnego doświadczenia zawodowego, obserwacji oraz znajomości arkuszy egzaminacyjnych wyrażali swoje spostrzeżenia na temat istotnych dla nich przemian w egzaminie gimnazjalnym. W wywiadzie nie zastosowano pytań odnoszących się do poszczególnych reform, po to by uniknąć sugerowania ważności zachodzących zmian. Pedagodzy sami decydowali o tym, co jest istotą poruszanego zagadnienia, a zadaniem badacza było uzyskanie jak najobszerniejszych opisów na temat przemian $\mathrm{w}$ egzaminie gimnazjalnym. Wywiad prowadzony był $\mathrm{w}$ formie indywidualnej - podczas jego trwania rozmawiano tylko z jednym respondentem. Miał on charakter jawny, co oznacza, że badani byli w pełni świadomi celu prowadzonej z nimi rozmowy.

Badania przeprowadzono w Specjalnym Ośrodku Szkolno-Wychowawczym (SOSW) w województwie pomorskim na przełomie lutego i kwietnia 2017 roku. $\mathrm{W}$ wyborze grupy badawczej kierowano się, by badani mieli wieloletnie doświadczenie w pracy na etapie gimnazjum, co stwarzało szansę jak najszerszej znajomości kwestii objętych badaniem. By poznać opinie różnych pracowników, badania przeprowadzono z dyrekcją jak i z gronem pedagogicznym Ośrodka.

$\mathrm{Z}$ kadry kierowniczej ośrodka wywiady przeprowadzono $\mathrm{z}$ dyrektorem i wicedyrektorem:

- dyrektor pełni swoje stanowisko od 2000 r., zatem od czasu wprowadzenia reformy i pojawienia się w szkole gimnazjum;

- wicedyrektor placówki związana jest z Ośrodkiem od ponad 37 lat - początkowo pracując jako pedagog specjalny, a obecnie odpowiedzialna za kwestie organizacyjne związane z egzaminami zewnętrznymi, w tym egzaminami gimnazjalnymi.

Wśród grupy badawczej złożonej z pedagogów specjalnych specjalizujących się w nauczaniu konkretnych przedmiotów znalazło się pięciu nauczycieli z wieloletnim stażem pracy:

- nauczyciel matematyki z ponad dwudziestoletnim doświadczeniem zawodowym; 
- nauczyciel historii i wiedzy o społeczeństwie z ponad dwudziestoletnim doświadczeniem zawodowym;

- pedagog specjalny prowadzący terapię dla uczniów z autyzmem i jednocześnie nauczyciel geografii $-\mathrm{z}$ kilkunastoletnim doświadczeniem zawodowym jako geograf;

- nauczyciel języka niemieckiego z dziesięcioletnim stażem pracy w SOSW oraz poprzedzającym je długoletnim doświadczeniem $\mathrm{w}$ zawodzie germanisty w szkole masowej;

- nauczyciel fizyki, który swoją drogę ze Specjalnym Ośrodkiem Szkolno-Wychowawczym rozpoczął w 2000r., początkowo nauczając chemii, fizyki, techniki i informatyki, a na chwilę obecną uczy fizyki w klasach gimnazjalnych oraz techniki i informatyki na etapach szkoły podstawowej i gimnazjalnej.

Wywiady były nagrywane a następnie poddane transkrypcji czyli uporządkowaniu w postaci plików tekstowych. Proces ten wymagał czasu i wiązał się z kodowaniem i z interpretacją treści. W przypadku większości badań zorientowanych jakościowo kodowanie pełni kluczową rolę w procesie analizy. G. Gibbs [2015, s. 83, 103] o kodach pisze następująco: „kody wyznaczają główny kierunek myślenia o tekście i jego interpretacji. Konkretny zakodowany tekst jest jednym z przejawów tego ukierunkowania. (...) W przypadku większości badań zorientowanych jakościowo kodowanie pełni kluczową rolę w procesie analizy. Polega ona na wskazaniu jednego lub więcej akapitów w tekście, które ilustrują wybrany wątek tematyczny, a następnie opisaniu ich za pomocą odpowiedniej etykiety, która w skrótowy sposób odsyła do kodowanego zagadnienia. Po zakodowaniu tekstu można wyszukiwać fragmenty opatrzone tymi samymi etykietami i śledzić różnice oraz zmiany w kodowaniu między poszczególnymi przypadkami, a także zestawiać ze sobą teksty zakodowane na różne sposoby". Dzięki temu zabiegowi nie czytano wielokrotnie tego samego tekstu, aby wyodrębnić z niego odpowiednie treści.

\section{Nauczycielska ocena przemian w egzaminie gimnazjalnym dla uczniów z niepełnosprawnością intelektualną w stopniu lekkim oraz planów likwidacji gimnazjum - wyniki badań}

Z prezentowanych przez pedagogów stanowisk wyłoniono pola, którym nauczyciele poświęcili szczególną uwagę. Wśród takich obszarów znalazły się: problemy wymagań egzaminacyjnych, w tym możliwość udzielanego uczniom wsparcia $\mathrm{w}$ trakcie egzaminu, problem struktury egzaminu, a także możliwości intelektualnych uczniów. W polu wypowiedzi pojawiła się też planowana reforma oświaty. 
Pole trudności związane z wymaganiami egzaminacyjnymi odnieść można kilku kwestii. Nauczycielka matematyki kreśli analizę w długiej perspektywie czasowej stwierdzając: „Kiedy egzaminy zostały wprowadzone, wtedy były zdecydowanie łatwiejsze (...)" - a zatem zwraca uwagę na rosnący, jej zdaniem, z biegiem czasu stopień trudności w przypadku egzaminów gimnazjalnych dla uczniów z lekką niepełnosprawnością intelektualną. $\mathrm{W}$ dalszej części wypowiedzi pedagog, z nieco ironicznym akcentem tłumaczy przyczynę zaistniałego zjawiska: „(...) Przede wszystkim dlatego, że wówczas szkoły, jak nasza, pracowały na podstawie programowej stworzonej do naszej szkoły, a nie mądry wymysł, że działamy na podstawie podstawy programowej ogólnej". Na zmianę kryteriów w egzaminie gimnazjalnym zwróciła uwagę również nauczycielka niemieckiego, która podziela opinię swojej poprzedniczki, sugerując, że zbyt wysokie wymagania na egzaminie mogą wynikać z obowiązującej podstawy programowej: „Wydaje mi się, że ze względu na tę podstawę programową trochę jest jednak cały czas zawyżony poziom, porównując kwalifikacje i możliwości naszych uczniów".

Nauczyciele zwracają uwagę na obszerność materiału, który od czasu przeprowadzania egzaminów zgodnie z podstawą programową uczniowie mają do przyswojenia. Matematyczka opisuje te zmiany w zakresie prowadzonego przez siebie przedmiotu: „(...)To się zmieniło od tej podstawy programowej, ponieważ są tu pierwiastki, bardzo trudno jest potęgę wprowadzić... no jeszcze kwadrat, a już te wszystkie inne wyższe... Kwadrat, sześcian - ta podstawa to tak jeszcze mniej więcej do wyuczenia. Ale pierwiastek - że to jest odwrotność - to abstrakcja!". Nauczycielka podkreśla także kluczową rolę podstawy programowej w konstruowaniu egzaminów gimnazjalnych, która w przypadku uczniów z niepełnosprawnością intelektualną w stopniu lekkim stanowi zbyt wysoką poprzeczkę. Wicedyrektor, odnosząc się do zmian w egzaminie z części matematycznej podziela zdanie nauczycielki uczącej ten przedmiot, na co wskazują słowa: „A wzory dla naszych uczniów to jest w ogóle abstrakcja".

Podobne wnioski wysnuwa nauczycielka historii i WOS-u, która, analizując wielokrotnie arkusze egzaminacyjne, nie dostrzega $w$ nich zapewnianego w nazwie dostosowania do możliwości uczniów. W przypadku historii, zdaniem pedagog: „(...) te egzaminy są tak skonstruowane, że jeżeli na przykład dziecko ma czytać wykres, a wykres jest dla niego też już zaburzeniem tekstu, więc tutaj nie można takich rzeczy stosować. Mimo, że my możemy ćwiczyć (...), ale jak on dostanie inny wykres, tabelę albo urywek tej tabeli, to już nie potrafi jej odczytać, ponieważ to nie jest taka, która była ćwiczona na lekcji".

W dłuższej perspektywie czasowej pole trudności związanych z udzielaniem uczniom wsparcia w trakcie egzaminu analizuje wicedyrektor ośrodka: „Jeszcze na samym początku jak egzaminy wprowadzano w 2000 r. czy w 2002 r., już nie pamiętam, to można było im raz odczytać tekst. A teraz nie wolno". Zmianę tę wi- 
cedyrektor ocenia za bardzo niekorzystną, tłumacząc, iż na chwilę obecną uczniowie mimo posiadanej wiedzy uzyskują niskie wyniki ze względu na problemy z czytaniem: „I teraz bardzo słabo wypada uczeń, który ma wiedzę, potrafi to zrobić, a ma wielki problem z czytaniem". W zaistniałej zmianie przyczynę trudności i niepowodzeń uczniów także dostrzega dyrektor placówki: „Wcześniej, gdy był nauczyciel, który mógł przeczytać jasno i wyraźnie tekst uczniowi to im bardzo pomagało. Na obecnym etapie nie wolno czytać naszym uczniom i to jest jakby podstawa ich niepowodzeń".

Nauczycielka niemieckiego wzmiankuje o przedłużonym czasie, jaki przysługuje uczniom na egzaminie, a który tak naprawdę na nic się zdaje, jeśli uczniowie nie rozumieją poleceń: „Bo ten przedłużony czas tak naprawdę nie jest im potrzebny, bo jeżeli nie wiedzą co mają robić to i tak wychodzą szybciej". W dalszej części wywiadu pedagog wyraża przekonanie, że możliwość pomocy uczniowi w trakcie egzaminu wpłynęłaby korzystnie na wyniki uczniów: „a myślę, że przy wsparciu nauczyciela napisaliby dużo lepiej. Zwłaszcza, że są do tego przyzwyczajeni". Przyzwyczajenie to wynika z częstej możliwości pomocy nauczyciela na lekcji, który: „tłumaczy zadanie trzy, a czasami cztery razy, bo jeszcze ktoś tam nie usłyszał... jeszcze nie wie do końca". Nauczycielka uważa, że wsparcie na egzaminie gimnazjalnym byłoby jak najbardziej uzasadnione, zważywszy, że uczniowie uzyskują je na dalszym etapie życia: „Tak samo oni dalej w pracy - wszędzie potem dostają to wsparcie, oni potrzebują tego wsparcia i wydaje mi się, że tutaj byłaby uzasadniona możliwość żeby móc wytłumaczyć w trakcie egzaminu".

Problem trudności egzaminów odnoszony był też przez badanych do systemowych rozwiązań dialogu ze środowiskiem nauczycieli. Przeprowadzane początkowo egzaminy mogły być poddawane nauczycielskiej ocenie za pomocą ankiety, w której pedagodzy zamieszczali swoje uwagi i spostrzeżenia. Wicedyrektor wspominając ten fakt, odnosi się do niego z dużą rezerwą, uważając, że ankiety, które teoretycznie powinny służyć ewaluacji egzaminów, w rzeczywistości nie odgrywały takiej roli. Zdaniem Wicedyrektor: „nikt nie brał tych uwag pod wzgląd". Na potwierdzenie głoszonego stanowiska pedagog podaje taki przykład: „Na matematyce było pytanie z błędem, my to zaznaczyłyśmy, że w pytaniu jest błąd i to pytanie się powtórzyło po paru latach". Wicedyrektor nadmienia, że nie jest osamotniona w takim przekonaniu, gdyż konsultując się z nauczycielami pracującymi w placówkach $\mathrm{w}$ innych miastach stykała się z podobnymi odczuciami pedagogów.

Nauczyciele koncentrowali się w swoich wypowiedziach także na zmianach $\mathrm{w}$ strukturze egzaminu, $\mathrm{z}$ uwzględnieniem indywidualnych umiejętności uczniów. Nauczycielka niemieckiego stwierdza, że na przestrzeni ostatnich dziesięciu lat pracy w Specjalnym Ośrodku Szkolno-Wychowawczym nie zauważyła znaczących różnic dotyczących budowy egzaminu: „Cały czas tak naprawdę 
punkty są te same: jest rozumienie ze słuchu, rozumienie tekstu czytanego, są pytania, łączenia, obrazki, interakcje, więc ja nie zauważyłam jako takich naprawdę znaczących zmian, które były 5 lat temu, a w tej chwili jaki był egzamin". Wyniki egzaminów, zdaniem nauczycielki, uzależnione są od możliwości uczniów: „Bardziej to zależy od rocznika i uczniów tak naprawdę. Czasami się zdarzają w klasie trochę zdolniejsi uczniowie, w związku z tym jest to trochę łatwiejsze, a czasami uczniowie słabsi". Dyrektor placówki, odnosząc się do zmian wykazuje podobny punkt widzenia do nauczycielki. Jego zdaniem następujące zmiany i wprowadzanie kolejnych części nie odznaczały się istotnym zróżnicowaniem w stosunku do egzaminów z ubiegłych lat, na co wskazują słowa: „My nie zauważamy wielkich różnic, przeważnie jest to na tym samym poziomie". W dalszej części wypowiedzi Dyrektor podkreśla, że klasy są bardzo zróżnicowane pod względem poziomu uczniów, czego skutkiem są dysproporcje wyników, ponadto: „Klasy są nieliczne... ośmioro, sześcioro liczą i wystarczy, że w takiej klasie trafi się dwoje, troje uczniów o bardzo niskim poziomie i automatycznie zaniża wynik". W związku z tym, pedagodzy, analizując wyniki, oceniają je tylko pod kątem indywidualnych osiągnięć uczniów, o czym świadczą słowa: „U nas nie bierzemy średniej oddziału, grupy - tylko indywidualnie jakie postępy zrobił uczeń". Natomiast biorąc pod uwagę zmiany kryteriów i struktury egzaminu, Dyrektor wypowiada się następująco: „Tak jak mówiłem, w naszym przypadku nie ma tutaj żadnych różnic. Trzeba podchodzić indywidualnie. To rozszerzenie, wprowadzenie też języka.. nie widzimy tu żadnych różnic... My patrzymy indywidualnie na każdego ucznia".

Kwestia możliwości intelektualnych uczniów pojawia się też w nieco innym kontekście. Zdaniem nauczycielki geografii: „(..) dzieci są coraz bardziej zaburzone". Pedagog nie jest odosobniona w tym przekonaniu, gdyż nauczyciel fizyki zwraca również uwagę na możliwości uczniów, które na przestrzeni lat uległy ograniczeniu: „dzieci są trudniejsze” - jak twierdzi pedagog. Aby lepiej zobrazować tę sytuację nauczyciel podaje przykład: „Mam zadania, które kiedyś dawałem klasom trzecim, a teraz nie mogę ich dać. Muszę je najpierw przekształcić, pozmieniać, zadań dać mniej. Każdy moduł rozbić tematycznie na drobne tematy, bo dziecko nie da rady". Za przyczynę tej trudności nauczyciel upatruje prawo, w którym to rodzic wybiera placówkę dla swojego dziecka: „Z racji tego, że kiedyś było tak, że dwa lata dzieciak nie zdawał i automatycznie był przerzucany do szkoły specjalnej. Obecnie teraz nie jest to automatyczne, rodzic ma w swojej gestii to, że dziecko przychodzi do danej szkoły". W rezultacie uczeń z orzeczeniem o niepełnosprawności intelektualnej $\mathrm{w}$ stopniu lekkim albo nie trafia do szkoły specjalnej albo pojawia się w niej bardzo późno. Ma to duże znaczenie, gdyż jak oświadcza nauczyciel: „,same arkusze i same testy są według tych samych wytycznych, i są też różnice, są łatwiejsze, bardziej dostępne, aczkolwiek dla naszych dzieci coraz trudniejsze". 
Pole trudności dotyczące struktury egzaminu poddaje krytycznej analizie wicedyrektorka placówki, odnosząc się w swej ocenie do zmian jakie nastąpiły na przestrzeni lat. Wicedyrektorka przypomina początkową strukturę egzaminu złożoną z dwóch części: humanistycznej oraz matematyczno-przyrodniczej, a także wprowadzonego później egzaminu z języka obcego, które zostały przekształcone: „Teraz mamy jedną część humanistyczną rozdzieloną na dwie i... to by mogło tak zostać według mnie". Część humanistyczna składa się na chwilę obecną z języka polskiego oraz historii i wiedzy o społeczeństwie. Uczniowie przystępujący do egzaminu najpierw rozwiązują część historyczną, po czym następuje przerwa i kolejna część egzaminu - z języka polskiego. Wicedyrektorka wyraża silne niezadowolenie z następującej kolejności egzaminu: „My uważamy, że najpierw polski, a dopiero po przerwie WOS. Dlatego, że na polskim oni się muszą bardzo mocno skupić. WOS to jest - pytania zamknięte, generalnie są zadania zamknięte. (...) to jest dla nich prostsze. I od lat nasi uczniowie z WOS-u wypadają lepiej. Bo to jest pierwsza część, rano przychodzą, jeszcze nie są zmęczeni i oni tę część robią szybko". Po pierwszej części egzaminu następuje, cytując słowa wicedyrektor "nieszczęsna przerwa”, po której uczniowie rozpoczynają część z języka polskiego. Analogicznie do części humanistycznej ma miejsce sytuacja z kolejnością egzaminów z części matematyczno-przyrodniczej, w których egzamin z matematyki odbywa się po egzaminie z części przyrodniczej. Skutki takiej kolejności, podobnie do egzaminu odbywającego się pierwszego dnia, są widoczne w rezultatach na egzaminie, o czym wzmiankuje Wicedyrektor: „z części matematyczno-przyrodniczej z matematyki od tej pory zaczęliśmy mieć znacznie gorsze wyniki".

Planowana reforma likwidacji gimnazjum stanowiła wyraźne pole w wypowiedziach nauczycieli, chociaż zaobserwowano, iż pedagodzy nierzadko mieli trudności z ustosunkowaniem się do tych zmian, co wyrażały sformułowania: "Trudno mi się wypowiedzieć”, „Nie mam pomysłu jak to teraz będzie wyglądać. Ciężko stwierdzić”; "Czy zmiana będzie korzystna to się okaże”. Nauczycielka historii i WOS-u uznała, że na chwilę obecną nie można dokonać oceny przewidywanej reformy, gdyż jak to określa: „wszystko jest gdzieś tam w powijakach i nie ma tego materiału rzeczywistego". W dalszej części wypowiedzi pedagog objaśnia kryteria, które bierze pod uwagę przy ocenie przemian: „Jeżeli mówimy o pozytywach czy negatywach to w momencie kiedy jesteśmy w stanie powiedzieć jak to wpływa na ucznia, a nie jak na nauczyciel", gdyż pedagog potrafi się dostosować do następujących zmian, a uczeń nie zawsze.

W kontekście likwidacji gimnazjum nauczycielka geografii dostrzega pozytywy wynikające z istniejącego swego czasu ośmioklasowego systemu szkoły podstawowej i zamiaru powrotu do tej struktury. Jej zdaniem: „(...) poprzedni system 8 klas plus $4 \mathrm{w}$ liceum i $5 \mathrm{w}$ technikum był dobrym systemem. Wówczas uczeń był 
w szkole macierzystej przez 8 lat, a zatem w wieku dorastania - jego najbardziej burzliwym okresie". Zdaniem pedagog, w takim systemie nauczyciele znali ucznia od najmłodszych lat i łatwiej było im reagować na problemy wychowawcze nasilające się w okresie dorastania, a więc na etapie obecnej szkoły gimnazjalnej. Nauczycielka uważa, iż na chwilę obecną uczniowie przybywający do pierwszej gimnazjum, często trafiają do nowej szkoły i stają się anonimowi. W celu zwrócenia na siebie uwagi uczniowie popisują się i nauczyciel musi niejednokrotnie silnie się natrudzić, by nakierować uwagę uczniów na omawiane zagadnienia i jak twierdzi pedagog: „zyskać w ich oczach szacunek”. Nauczycielka puentuje swoją opinię słowami: „Także jeśli chodzi o system wychowawczy to lepszy jest system $8+4$. To jest na plus".

W odniesieniu do planowanej likwidacji gimnazjum z perspektywy nauczyciela fizyki wyłania się obraz dostrzeganej dezorganizacji i nieładu $\mathrm{w}$ działaniach reformatorskich. Z punktu widzenia pedagoga obecna sytuacja prezentuje się w następujący sposób: „Wprowadzono gimnazja. Były efekty kształcenia. Było lepiej. I naraz likwidują gimnazja. Wszystko jest przewrócone do góry nogami". Zdaniem nauczyciela najgorsze jest to, że reforma obejmie swym zasięgiem cały system, a nie jest skierowana do wybranej grupy, co według pedagoga pociągnie za sobą olbrzymie koszty. W podobnym duchu wypowiada się nauczycielka matematyki. Wyrażając swoje zdanie na temat zbliżającej się reformy nie może powstrzymać ironii, z której wyraźnie wynika, iż Polska nie jest na tyle bogatym krajem, by móc pozwolić sobie na reformę całego systemu: „Jesteśmy tak bogatym krajem, mamy tyle pieniędzy, że to jest nam naprawdę bardzo potrzebne (...)".

Pejoratywne nastawienie do reformy można odczytać także z wypowiedzi wicedyrektorki. Określa ona bowiem mające nadejść zmiany jako: „totalne zamieszanie" $i$ „bałagan”. W odniesieniu do placówek specjalnych wicedyrektorka stwierdza, iż wprowadzenie zmian będzie szczególnie trudne ze względu na przyzwyczajenie i zaznajomienie się uczniów z obecnym systemem, co wiąże się z odczuwanym przez podopiecznych poczuciem bezpieczeństwa. Zmiana systemu będzie dla uczniów równoznaczna z zaburzeniem dotychczasowych zasad, co pedagog wyraźnie zaznacza w swojej wypowiedzi: „(...) dla nas to jest w ogóle tragedia, bo oni się już wyuczyli. W podstawówce jest tak, w gimnazjum jest tak, potem przychodzi do zawodówki i w zawodówce jest tak. Wszystko im się zaburza". Wicedyrektorka, kontynuując swoją wypowiedź podkreśla, że opinie na temat nadchodzącej reformy są podzielone: „Jedni się cieszą, inni się nie cieszą”. Własną perspektywę wyraża słowami: „według mnie to jest bałagan”.

Nauczycielka matematyki, poddając planowaną reformę analizie, zwraca uwagę na to, że zmiany, które Ministerstwo ma zamiar wprowadzić, tak naprawdę nie są niczym nowym, gdyż planowany system już kiedyś w Polsce istniał: „bo to wszystko to co teraz, o czym się mówi, oczywiście wszystkiego nie wiem, bo 
wiadomo, że jeszcze nie ma tych wyznaczników i tak dalej, ale wszystko o czym się mówi to już kiedyś było. No to nie jest nic nowego. Odwrócenie kota ogonem". Jednak trud i praca włożone we wdrożenie obecnie istniejącego systemu są, zdaniem nauczycielki tak ogromne, że nie powinno się marnować tych wysiłków i wprowadzać kolejnych przemian. Pedagog objaśnia to w następujący sposób: „Ale skoro już to zrobiliśmy i coś wypracowaliśmy, no bo to była jakaś praca i to ciężka, żeby to zmienić, żeby się przyzwyczaić do nowego, żeby tą młodzież przyzwyczaić do nowych warunków i w ogóle".

Planowana reforma oświaty, będąca przedmiotem nauczycielskiej analizy spotyka się również z niezadowoleniem nauczycielki niemieckiego, która nie kryje frustracji wynikającej z braku przygotowania Polski do planowanych zmian. Pedagog swoją wypowiedź rozpoczyna od zajęcia jasnego stanowiska w tej sprawie: „Ogólnie ta reforma w ogóle nie podoba mi się, że tak powiem”. Zdaniem pedagog: „Polska w ogóle nie jest przygotowana do tej reformy”, w związku z czym nauczycielka uważa jej przeprowadzenie na chwilę obecną za całkowicie bezsensowne. Germanistka sądzi, że zarówno nauczyciele, uczniowie jak i budynki szkolne nie są przygotowane na zapowiadane zmiany, a podsumowuje to słowami: „Nic nie jest przygotowane tak naprawdę nigdzie”. Cała reforma, zdaniem nauczycielki, na chwilę obecną nie ma sensu, gdyż: „została zrobiona na szybko, byle jak. Byle by tylko ją wprowadzić".

Pole planowanych przemian poddaje ocenie również dyrektor placówki, odwołując się do posiadanego doświadczenia: „Myślę - to jest moje zdanie - jako osoby z wieloletnim doświadczeniem dyrektora, że nie powinno się wprowadzać zmian tak szybko". Wprowadzenie zmian, zdaniem dyrektora powinno być poprzedzone ich wcześniejszą weryfikacją: „Zmiany powinny być sprawdzone na jakiejś próbie, powinna być ona dokonana i dopiero potem wprowadzanie tego wszystkiego". Częste zmiany są, w opinii dyrektora olbrzymim utrapieniem, które wprowadza: „tylko niepotrzebne zdenerwowanie i chaos”, i jak dodaje: „To chyba nam najbardziej przeszkadza w naszej codziennej pracy". Dyrektor puentuje, iż: „Tak naprawdę nie wiadomo jak to będzie", co uważa za największy problem w pracy, gdyż brak informacji uniemożliwia długoterminowe planowanie. Konkludując, perspektywę głoszoną przez dyrektora można porównać do walki z wiatrakami, o czym świadczą słowa: „Jak coś wypracujemy to później to szybciutko legnie w gruzach i na nowo budujemy. I znowu będziemy budować cały system. Od podstaw". 


\section{Podsumowanie}

Można pokusić się o stwierdzenie, iż zmiany są nieodłącznym elementem systemu polskiej oświaty. Zagłębiając się w historię przemian w edukacji, wyraźnie widać nieustannie pojawiające się $\mathrm{w}$ niej reformy o olbrzymim zasięgu jak i modyfikacje, których zakres obejmuje mniejszy obszar. Każdą reformę i przemianę można ocenić za pomocą zestawienia aktualnej sytuacji w stosunku do stanu przed zajściem zmian. O taki bilans zmian w obrębie egzaminów gimnazjalnych dla uczniów z niepełnosprawnością intelektualną w stopniu lekkim pokusili się uczestniczący w badaniu nauczyciele i dyrekcja Specjalnego Ośrodka Szkolno-Wychowawczego z jednej z pomorskich miejscowości. Pedagodzy na podstawie własnego doświadczenia zawodowego, znajomości arkuszy egzaminacyjnych, znajomości regulacji prawnych dotyczących egzaminów ustosunkowywali się do przemian w egzaminie gimnazjalnym. Kluczową kwestią była dostrzegana przez nich problematyczność wymagań egzaminacyjnych i ograniczona możliwość udzielania uczniom wsparcia $\mathrm{w}$ trakcie egzaminu. Słabości postrzegano także w kolejności realizacji egzaminów, przy braku krytycznych ocen związanych ze strukturą egzaminu. Niskie wyniki wiązano z niskimi możliwościami uczniów, a funkcję wyników postrzegano w wymiarze indywidualnym.

Ustosunkowanie się do zmian, jakie miały miejsce $\mathrm{w}$ egzaminie gimnazjalnym, dla każdego z badanych obejmowało (z uwagi na jego doświadczenie zawodowe) różne ramy czasowe. Realny czas tych zmian odnieść można do ostatnich dwóch dekad. O ile oczywiste wydaje się podanie momentu - punktu inicjalnego obszar wypowiedzi nauczycieli, o tyle czas zamykający ten obszar był trudny do przewidzenia. Badani nauczyciele $\mathrm{w}$ swoich wypowiedziach wykraczali poza wydarzenia przeszłe i odnosili się do antycypowanej przyszłości. Rok 2017 był bowiem ostatnim rokiem istnienia gimnazjum - zgodnie z decyzją Ministerstwa Edukacji Narodowej od roku szkolnego 2017/2018 ten etap kształcenia planowano zastąpić istniejącą niegdyś ośmioletnią szkołą podstawową. Pomimo zarysowujących się różnic w ocenach antycypowanych wydarzeń, dało się zauważyć przewidywanie zagrożenia poczucia bezpieczeństwa uczniów i nauczycieli. Odczuwana niepewność i mglistość planowanych zmian z pewnością nie gwarantuje tego, by nauczyciele byli gotowi praktycznie wdrażać zaplanowane przemiany.

Nauczycielskie spojrzenie na zmiany nie jest wolne od dostrzegania powiązania reform z polityką i władzą kraju. Szczególnie wyraźnie zaznacza się w nich świadomość braku wpływu na zmiany. Nie trudno w tym kontekście nie zgodzić się ze słowami Bogusława Śliwerskiego [2008, s. 103-104], który brak możliwej odpowiedzi negatywnej na pytanie, czy reforma oświaty okazała się sukcesem wyjaśnił następująco: „Powód tak prostej i jednoznacznej oceny jest bardzo prosty - 
wszędzie tam, gdzie zmianę wprowadza odgórnie władza państwowa z wykorzystaniem całego swojego aparatu władzy, dominacji, a więc różnych, jawnych oraz skrytych środków kontroli i przymusu, wzbudzających wśród nauczycieli poczucie administracyjnego obowiązku, ale i zarazem lęku o miejsce pracy, efekt musi być przynajmniej na pozór pozytywny".

\section{Bibliografia}

Barłóg K. (2008), Wspomaganie rozwoju dzieci z niepetnosprawnościa intelektualną w stopniu lekkim w różnych formach edukacji wczesnoszkolnej, Wydawnictwo Uniwersytetu Rzeszowskiego, Rzeszów.

Chrostowska T., Mosiek T. (2001), Ministerstwo Edukacji Narodowej o egzaminie gimnazjalnym, MEN, Biuro Administracyjne, Warszawa.

Czerepaniak-Walczak M. (2002), Świadomość podmiotów edukacji gimnazjalnej - perspektywa pedagogiczna, Wydawnictwo Hogben, Szczecin.

Denek K. (2005), Ku dobrej edukacji, WHS Torun-Leszno.

Denek K. (2008), Toczaca się reforma edukacji [w:] Tocząca się reforma edukacji w dialogu i perspektywie, red. A. Karpińska, Trans Humana, Białystok.

Draus J., Terlecki R. (2005), Historia wychowania, t. 2, Wydawnictwo WAM, Kraków.

Gibbs G. (2015), Analizowanie danych jakościowych, PWN, Warszawa.

Informator o egzaminie gimnazjalnym od roku szkolnego 2011/2012, opracowany przez Centralną Komisję Egzaminacyjną we współpracy z okręgowymi komisjami egzaminacyjnymi w Gdańsku, Jaworznie, Krakowie, Łodzi, Łomży, Poznaniu, Warszawie i Wrocławiu oraz Instytutem Badań Edukacyjnych w Warszawie, Warszawa 2010, http://www.oke.krakow.pl/inf/filedata/files/Informator\%20gimnazjalny\%20od\% 20 2011-2012.pdf [dostęp: 28.03.2017].

Kocór M. (2006), Nauczyciele wobec zmian edukacyjnych w Polsce, Wydawnictwo Uniwersytetu Rzeszowskiego, Rzeszów 2006.

Kocór M. (2014), Nauczyciel wobec reformy, reforma wobec nauczyciela. Ku polityce partnerstwa i dialogu edukacyjnego [w:] Edukacja jutra. Systemowe aspekty organizacji szkolnictwa w Polsce, red. K. Denek, A. Kamińska, P. Oleśniewicz, Oficyna Wydawnicza „Humanitas”, Sosnowiec.

Konarzewski K. (2004), Reforma oświaty podstawa programowa i warunki kształcenia, Instytut Spraw Publicznych, Warszawa.

Komunikat dyrektora Centralnej Komisji Egzaminacyjnej z dnia 31 marca 2010 r. w sprawie sposobu dostosowania warunków i formy przeprowadzania sprawdzianu i egzaminu do potrzeb uczniów (słuchaczy) ze specjalnymi potrzebami edukacyjnymi od roku szkolnego 2010/2011, Warszawa 2010, file://C:/Users/LENOVO/Downloads/dostosowania_sp_gim_2011.pdf [dostęp: 20.04.2017].

Rozporządzenie Ministra Edukacji Narodowej z dnia 21 marca 2001 roku w sprawie warunków i sposobu oceniania, klasyfikowania i promowania uczniów i słuchaczy oraz przeprowadzania egzaminów i sprawdzianów w szkołach publicznych [Dz. U. z 2001 r. Nr 29, poz. 323]. 
Komunikat dyrektora Centralnej Komisji Egzaminacyjnej z 9 września 2016 r. w sprawie szczegółowych sposobów dostosowania warunków i form przeprowadzania egzaminu gimnazjalnego w roku szkolnym 2016/2017 http://oke.waw.pl/files/oke_waw_70620160909 $\%$ 20Komunikat\%20o\%20dostosowaniach\%20Egzamin\%20gimnazjalny.pdf.pdf [dostęp: 28.03.2017].

Rozporządzenie Ministra Edukacji Narodowej z dnia 23 grudnia 2008r. w sprawie podstawy programowej wychowania przedszkolnego oraz kształcenia ogólnego w poszczególnych typach szkół (Dz. U. z 2009 r. Nr 4, poz.17).

Rozporządzenie Ministra Edukacji Narodowej z dnia 30 kwietnia 2007r. w sprawie warunków i sposobu oceniania, klasyfikowania i promowania uczniów i słuchaczy oraz przeprowadzania sprawdzianów i egzaminów w szkołach publicznych [Dz. U. z 2007 r. Nr 73, poz. 562].

Rozporządzenie Ministra Edukacji Narodowej z dnia19 kwietnia 1999 r. w sprawie zasad oceniania, klasyfikowania i promowania uczniów i słuchaczy oraz przeprowadzania egzaminów i sprawdzianów w szkołach publicznych [Dz. U. Nr 41, poz. 413; z 2000 r. Nr 6, poz. 72 i Nr 115, poz. 1201].

Sadowska S. (2013), Egzamin gimnazjalny 2012 dla uczniów ze specjalnymi potrzebami edukacyjnymi - o jawnych $i$ ukrytych sposobach myślenia osób zaangażowanych we wdrażanie zmian, „Szkoła Specjalna”, nr 5.

Sadowska S., Janiszewska-Nieścioruk Z. (2015), Sukcesy w dziedzinie zewnętrznego sprawdzania efektów kształcenia uczniów z niepetnosprawnościami? Refleksje w odniesieniu do sprawdzianu po szkole podstawowej, „Niepełnosprawność. Dyskursy Pedagogiki Specjalnej” nr 20.

Szymański M. J. (2004), W poszukiwaniu drogi. Szanse i zagrożenia edukacji w Polsce, Wydawnictwo Naukowe Akademii Pedagogicznej, Kraków.

Śliwerski B. (2008), Edukacja pod prąd, Oficyna Wydawnicza „Impuls”, Kraków.

Ślusarczyk M. (2010), Spory o edukację wczoraj i dziś, Krakowska Akademia im. A. Frycz Modrzewskiego, Kraków.

Ustawa z dnia 8 stycznia 1999 r. - Przepisy wprowadzające reformę ustroju szkolnego [Dz.U z 1999 r. Nr 12, poz. 96].

Zahorska M. (1999), Jak nauczyciele oceniaja reformę edukacji [w:] Nauczyciele wobec reformy edukacji, red. E. Putkiewicz, K.E. Siellawa-Kolbowska, A. Wiłkomirska, M. Zahorska, Warszawa. 